Research Article

\title{
Effect of adding Silybum and Licorice Powder on Carbohydrate and Protein Concentration in Beans Grown in Soil Treated with Cobalt and Copper
}

\author{
Hussein Saber Mohammaed Ali Al-Rashedy ${ }^{*}$ and Wadullah Asaad Abdullah Al-Mtewti²
}

${ }^{1}$ Department of Biology, College of Education for Pure Science, University of Mosul, Mosul, Iraq; ${ }^{2}$ Directorate of Education Ninereh, Mosul, Iraq.

Abstract | Heavy metal pollution is one of the major environmental problems affecting all living organisms,
both animals and plants. This study aimed to determine the impact of adding powder of silybum and licorice
plants at concentrations 4 and $8 \mathrm{~g} / \mathrm{kg}$ soil each on the concentration of protein and carbohydrates in bean
plant seeds grown in soils contaminated with cobalt at concentrations 25 and 50 and copper at concentra-
tions 75 and $90 \mathrm{mg} / \mathrm{kg}$ soil. The soil was treated with the two plants powder to reduce the negative influences
of heavy elements by increasing the plant resistance. The study showed that treating the soil with silybum
powder at a concentration of $4 \mathrm{~g} / \mathrm{kg}$ soil gave the best result in the concentration of protein and carbohy-
drates, as it reached $4.88 \mathrm{mg} / \mathrm{g}$ for protein and $8.75 \mathrm{mg} / \mathrm{g}$ for carbohydrates. While the cobalt treatment at a
concentration of $50 \mathrm{mg} / \mathrm{kg}$ soil gave the lowest concentration of protein, which amounted to $0.46 \mathrm{mg} / \mathrm{g}$, and
for carbohydrates, which amounted to $1.87 \mathrm{mg} / \mathrm{g}$. The addition of silybum Powder at a concentration of $8 \mathrm{~g} /$
$\mathrm{kg}$ soil to plants grown in soils contaminated with cobalt at a concentration of $25 \mathrm{mg} / \mathrm{kg}$ soil gave the best
result with a concentration of protein and it amounted to $1.53 \mathrm{mg} / \mathrm{g}$. The addition of silybum powder at the
same concentration for plants grown in treatment soils with copper at a concentration of $75 \mathrm{mg} / \mathrm{kg}$, the soil
gave the best concentration for carbohydrates, and it reached $3.85 \mathrm{mg} / \mathrm{g}$ compared to the control treatment.
Received $\mid$ July 02,$2021 ;$ Accepted $\mid$ September 14,$2021 ;$ Published $\mid$ December 14,2021
*Correspondence $\mid$ Hussein Saber Mohammed Ali Al-Rashedy, Department of Biology, College of Education for Pure Science, University of
Mosul, Mosul, Iraq; Email: dr.husseinbio76@uomosul.edu.iq
Citation $\mid$ Al-Rashedy, H.S.M.A. and W.A.A. Al-Mtewti. 2022 . Effect of adding Silybum and licorice powder on carbohydrate and protein
concentration in beans grown in soil treated with cobalt and copper. Sarbad Journal of Agriculture, $38(1): 260-265$.
DOI $\mid$ https://dx.doi.org/10.17582/journalsja/2022/38.1.260.265
Keywords | Silybum, Licorice, Carbohydrate, Protein, Beans, Cobalt and copper

\section{Introduction}

$\mathrm{R}$ apid development in industry and manufacturing has caused environmental challenges worldwide, including heavy metals. which is considered a major threat to the environment and human health. The metals include arsenic, chromium, lead, nickel, cadmium, zinc and copper (Jaishankar et al., 2014; Kakkalameli et al., 2021). And The increase in heavy metal concentrations in the environment can be attributed to soil characteristics or different agricultural practices such as the use of fertilizers and pesticides and other agricultural operations (Foy et al., 2005). In addition to mining operations and the significant increase in the population (Emamverdian et al., 2015). Many reports show the many damages of heavy metals, which plants are usually the first target for (Arshad et al., 2008). Heavy metals are distinguished from other organic pollutants in that they are not degradable or transformed into harmless compounds by biological means, and they persist for a long time in the environment and enter the food chain (Chiban et al., 2011). As for copper, it is one of the important minerals in the oxidation and reduction processes in March 2022 | Volume 38 | Issue 1 | Page 260 
living systems. Small amounts of it are important in physiological processes, but increasing it has negative effects on different environmental systems. There are many studies concerning the role of copper in living organisms (Syed and Meshari, 2018). Cobalt is a heavy metal that is not necessary for plants that have seven possible oxidation states, and it can be a catalyst for reactions whose importance is clear in that it is involved in the activation of some enzymes, especially those involved in nitrogen fixation. It also has a role in delaying leaf ageing by inhibiting ethylene biosynthesis. and increased drought resistance in seeds ( $\mathrm{Pi}-$ lon-Smits et al., 2009). As for its toxic effects, it is related to oxidative stress, inhibition of photosynthesis and iron deficiency (Morrissey et al., 2009). As for the plant Silybum marianum, it is one of the plants that have been used for long periods for medicinal purposes. It is a member of the Asteraceae family. It is a herb that is characterized by its length, with green prickly leaves, and its flowers are purple, tend to be red and end with sharp spines. It is native to the Mediterranean region and has spread to Asia, Europe, Australia, and America. It is grown as a commercial crop in many countries, including Iran and Pakistan, and is a plant that converts to many chemical compounds that are used in the pharmaceutical industries (Porwal et al., 2019). The licorice plant is an excellent source of many medicinal compounds. The licorice plant of the Leguminosae family is a herbal plant of medicinal value. It contains many compounds such as isoliquiritin, glycyrrhizin, and glycyrrhizinic acid, which can provide us with medicinal benefits (Hasan et al., 2021). The study aimed to find out the effect of the element's cobalt and copper and the effect of adding silybum and licorice plant powder on the concentration of proteins and carbohydrates in the bean's seeds. Also, reduce the negative effect of heavy elements by adding powder from the two plants.

\section{Materials and Methods}

Agriculture: The seeds of the bean plant (Phaseolus vulgaris) were obtained from the offices of seed and planting materials in Nineveh Governorate/Iraq. The seeds were sown on 25/8/2019 by 4 seeds/pot, considering that the distances between the seeds are equal, and the pots were randomly placed under greenhouse conditions. After (65) days from the date of planting, the bean plants were harvested by (3) replicates per treatment.
Treatments: The treatments used in this study included two types of heavy metals: cobalt, with concentrations (25 and 50) and copper at concentrations (75 and 90$) \mathrm{mg} / \mathrm{kg}$ soil. The soil was treated with two types of wild plant powders: Silybum marianum and Glycyrrbiza glabra, with concentrations (4 and 8) g/ $\mathrm{kg}$ of soil for each.

\section{Measuring protein and carbohydrate concentration}

The protein was estimated based on (Lowry et al., 1951) method, by taking $0.5 \mathrm{~g}$ of the plant sample, using TCA, copper reagent, diluted Lowry's reagent. And reading the absorbance at the wavelength of 660 $\mathrm{nm}$. Bovine albumin was used for the standard curve. Estimate carbohydrates in $1 \mathrm{~g}$ of dried and crushed plant samples using a spectrophotometer and at a wavelength of $620 \mathrm{~nm}$ and the standard curve was used using glucose (Pearson et al., 1976).

\section{Statistical analysis}

The experiments were designed and statistically analyzed using the factorial experiment according to the Completely Randomized Design (C.R.D) in the factorial experiments, and the significant differences in transaction rates were compared using Duncan's New Multiple Range Test. And rates with similar letters do not differ significantly at the (5\%) probability level according to Duncan's polynomial test.

\section{Results and Discussion}

\section{Protein concentration}

Table 1 shows that soil treatment with cobalt at concentrations 25 and 50 and copper at concentrations 75 and $90 \mathrm{mg} / \mathrm{kg}$ soil led to a significant decrease in protein concentration in bean plant seeds compared to the control treatment. It was noted that the lowest concentration of protein appeared in bean plant seeds treated with cobalt at a concentration of 50 $\mathrm{mg} / \mathrm{kg}$ soil, which amounted to $0.46 \mathrm{mg} / \mathrm{gm}$. As for the treatment with plant powders, it was found that treating the soil with silybum and licorice powder at concentrations 4 and $8 \mathrm{gm} / \mathrm{kg}$ soil led to a significant increase in protein concentration. And the highest concentration of protein appeared when treated with silybum powder at a concentration of $4 \mathrm{gm} / \mathrm{kg}$ soil, and it reached $4.88 \mathrm{mg} / \mathrm{g}$ compared to the control treatment. It was also shown from the table that soil treatment at a concentration of $4 \mathrm{gm} / \mathrm{kg}$ soil was better than treatment with a concentration of $8 \mathrm{~g} / \mathrm{kg}$ soil as the effect of plant powder concentration, and 
Table 1: The effect of soil treatment with Silybum and licorice powder on protein $(\mathrm{mg} / \mathrm{g})$ concentration in beans grown in soils contaminated with heavy metals.

\begin{tabular}{lllllllll}
$\begin{array}{l}\text { Powder } \\
\text { type effect }\end{array}$ & $\begin{array}{l}\text { Powder concen- } \\
\text { tration effect }\end{array}$ & \multicolumn{2}{c}{ Cu mg/kg soil } & \multicolumn{2}{c}{ Co $\mathbf{~ m g / k g ~ s o i l ~}$} & Control & $\begin{array}{l}\text { Powder con- } \\
\text { centration }\end{array}$ & Powder type \\
$1.10 \mathrm{c}$ & $1.10 \mathrm{c}$ & $0.90 \mathrm{~h}$ & $1.09 \mathrm{~g}$ & $0.46 \mathrm{j}$ & $0.68 \mathrm{i}$ & $2.36 \mathrm{~b}$ & 0.0 & \\
$1.52 \mathrm{a}$ & $1.62 \mathrm{a}$ & $1.03 \mathrm{~g}$ & $1.41 \mathrm{de}$ & $1.08 \mathrm{~g}$ & $1.34 \mathrm{e}$ & $4.88 \mathrm{a}$ & 4 & Silybum powder gm/kg \\
& $1.17 \mathrm{~b}$ & $0.49 \mathrm{j}$ & $0.94 \mathrm{gh}$ & $1.04 \mathrm{~g}$ & $1.53 \mathrm{~d}$ & $1.49 \mathrm{~d}$ & 8 & \\
$1.28 \mathrm{~b}$ & & $0.95 \mathrm{gh}$ & $1.09 \mathrm{~g}$ & $1.01 \mathrm{~g}$ & $1.16 \mathrm{f}$ & $2.29 \mathrm{bc}$ & 4 & licorice powder \\
& & $0.65 \mathrm{i}$ & $1.28 \mathrm{ef}$ & $1.00 \mathrm{~g}$ & $1.41 \mathrm{de}$ & $1.91 \mathrm{c}$ & 8 & $\mathrm{gm} / \mathrm{kg}$ \\
& & & & $0.86 \mathrm{~b}$ & $1.19 \mathrm{a}$ & Element concentration effect
\end{tabular}

The letters express the significant differences. Different letters are considered to be a significant difference, while the similar letters mean no significant differences between the results.

Table 2: The effect of soil treatment with Silybum and licorice powder on carbohydrate $(\mathrm{mg} / \mathrm{g}$ ) concentration in beans grown in soils contaminated with heavy metals.

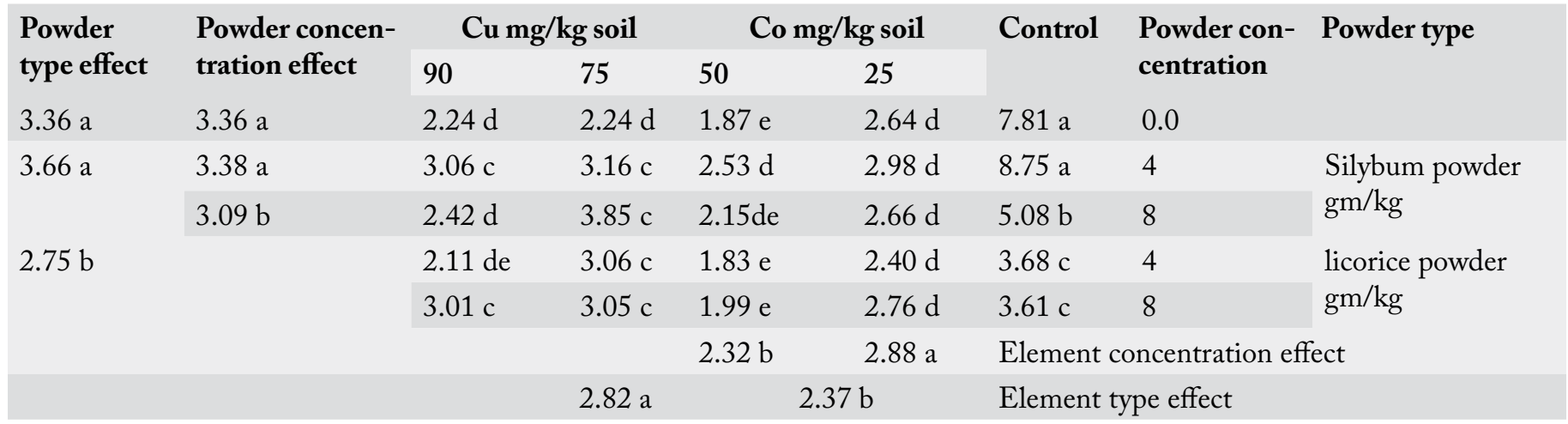

The letters express the significant differences. Different letters are considered to be a significant difference, while the similar letters mean no significant differences between the results.

it amounted to $1.62 \mathrm{mg} / \mathrm{g}$. It was found that treating the soil with silybum powder led to a significant increase in protein concentration, which amounted to $1.52 \mathrm{mg} / \mathrm{gm}$, compared to treating the soil with licorice powder and the control treatment. As for the effect of heavy element concentration, it was noted that soil treatment with the second concentration of each heavy element had the most significant and significant effect on the protein concentration, reaching $0.86 \mathrm{mg} / \mathrm{g}$. The copper element had the most significant effect on the protein concentration compared to the effect of the cobalt element, and it was 0.98 $\mathrm{mg} / \mathrm{g}$ as the effect of the element type on the protein concentration in the bean plant seeds. This may be because proteins are among the main targets of heavy elements, as they form side complexes with them or replace the main ions involved in the formation of proteins, which negatively affects their functions (Tamás et al., 2014). And those plants were exposed to different concentrations of heavy metals, which leads to oxidative stress in plants, which leads to an increase or decrease in the level of enzymes and dis- ruption of their work, which affects protein production (Oladele et al., 2019). Heavy metal may affect plants by causing oxidation of proteins and fats in the plant cell and the occurrence of damage to nucleic acids, as well as inhibiting enzymes, which affects the production of proteins (Adrees et al., 2015). Furthermore, the treatment with $\mathrm{Co}$ and $\mathrm{Cu}$ elements negatively affected the absorption of zinc, potassium and manganese and led to a significant decrease in plant growth and an increase in oxidative stress (ROS and MDA), but at the same time, there was an increase in the content of phytochelatin (PC) and glutathione (GSH and GSSG) (Jonas, 2020). This may affect the synthesis and concentration of proteins is similar to what was found by (Kakkalameli et al., 2021) that the exposure of Water lettuce plants to high concentrations of chromium led to a decrease in the concentration of both carbohydrates and protein.

\section{Carbohydrate concentration}

It was found from Table 2 that soil treatment with cobalt and copper and with the concentrations fixed March 2022 | Volume 38 | Issue 1 | Page 262 
in the above table showed a significant decrease in the carbohydrate concentration in bean plant seeds, and the treatment with cobalt at the concentration of 50 $\mathrm{mg} / \mathrm{kg}$ soil was the most effective and amounted to $1.87 \mathrm{mg} / \mathrm{gm}$ compared to the control treatment. As for the treatment with plant powders, it was found that treating the soil with silybum and licorice plant powder at concentrations 4 and $8 \mathrm{gm} / \mathrm{kg}$ soil led to a significant increase in carbohydrate concentration. And the treatment with silybum powder at a concentration of $4 \mathrm{gm} / \mathrm{kg}$ soil was significantly superior to the rest of the treatments and it reached $8.75 \mathrm{mg} / \mathrm{g}$. It was noted from the table that the treatment of soil with plant powders at a concentration of $4 \mathrm{gm} / \mathrm{kg}$ soil was better than treatment with a concentration of 8 $\mathrm{gm} / \mathrm{kg}$, as it was observed that the concentration of carbohydrates in the seeds was $3.38 \mathrm{mg} / \mathrm{g}$ as the effect of the concentration of the plant powder.

And as the effect of the type of powder, treatment with silybum powder led to a significant increase in carbohydrate concentration compared to treating the soil with licorice powder, and it amounted to $3.66 \mathrm{mg} / \mathrm{g}$ as for the effect of the concentration of the element, the second concentration of the two heavy elements was significantly more effective compared to the first concentration, and the concentration of carbohydrates was $2.32 \mathrm{mg} / \mathrm{g}$. And treatment with cobalt element significantly affected the concentration of carbohydrates in seeds compared to copper element as the effect of the element type, and it amounted to 2.37 $\mathrm{mg} / \mathrm{g}$. The decrease in carbohydrate content when treated with heavy metals may be attributed to the fact that heavy metals impeded metabolic activities that may reduce carbohydrate content, and a decrease in photosynthetic pigments, which leads to inhibition of photosynthesis activity, which reduces the proportion of carbohydrates (Hussain et al., 2013). The reason for the low content of carbohydrates may also be because heavy metals affect the photosynthesis of plants by reducing the content of chlorophyll and the absorption of the necessary elements for chlorophyll such as magnesium and iron, which affects the chloroplasts, and changes the basic enzymatic processes of the photosynthesis process, which negatively affects the content of carbohydrates in plant leaves (Alia et al., 2015). And possibly a decrease in photosynthetic pigments as a result of the negative effects of heavy elements in the plant (AL-Rashedy, 2020). And Plants treated with heavy metals had a decrease in the rate of photosynthesis, stomata conduction and transpiration rate (Alkhatib et al., 2019) This is one of the reasons that reduce the process of carbohydrate formation. This is similar to what was found (Selvaraj, 2018) in that the exposure of black gram plants to toxic concentrations of nickel led to a decrease in the concentration of photosynthetic pigments such as chlorophyll and carotenoids due to an imbalance in cellular systems, and this negatively affects the concentration of carbohydrates, which is the main product of the photosynthesis optical.

\section{Conclusions and Recommendations}

It was found from the research that the treatment of soil with heavy metals led to a significant decrease in the concentration of carbohydrates and protein in bean plants. The effect was greater with high concentrations of these minerals. Whereas, treating the soil with powder of wild plants improved and increased the concentration of protein and carbohydrates. Therefore, we recommend the use of other plant powders to treat the effect of heavy metals.

\section{Acknowledgements}

The author is very grateful to the University of Mosul/ College of Education for Pure Science/ Department of Biology for their provided facilities, which helped to improve the quality of this work.

\section{Novelty Statement}

The study is novel as it shows increase in the tolerance of plants and reduction of heavy metals when the soil is contaminated by using wild plant powders.

\section{Author's Contribution}

Hussein Saber Mohammaed Ali Al-Rashedy: Sample handling, laboratory testing, performed statistical analyses and research writing.

Wadullah Asaad Abdullah Al-Mtewti: Cultivation, sample handling, and search for sources.

\section{Conflict of interest}

The authors have declared no conflict of interests.

\section{References}

Adrees, M., S. Ali, M. Rizwan, M. Ibrahim, F. Abbas, M. Farid, M. Zia-Ur-Rehman, M. Irshad 
and S. A. Bharwana. 2015. The effect of excess copper on growth and physiology of important food crops: A review. Environ. Sci. Pollut. Res. 22: 8148-8162. https://doi.org/10.1007/ s11356-015-4496-5

Alia, N., S. Sardar, M. Said, K. Salma, A. Sadia, S. Sadaf, A. Touqir and S. Miklas. 2015. Toxicity and Bioaccumulation of Heavy Metals in Spinach (Spinacia oleracea) Grown in a Controlled Environment. Int. J. Environ. Res. Public Health. 7416-7400. https://doi.org/10.3390/ ijerph120707400

Alkhatib, R., M. Mheidat, N. Abdo, M. Tadros, L. Al-Eitan, K. Al-Hadid. 2019. Effect of lead on the physiological, biochemical and ultrastructural properties of Leucaena leucocephala. Plant Biol. 21(6). https://doi.org/10.1111/plb.13021

AL-Rashedy, H.S.M. 2020. Effect of cobalt and nickel on growth and some physiological aspects of mint (Mentha spicata). Plant Cell Biotechnol. Mol. Biol. 21(71\&72):163-171

Arshad, M., J. Silvestre, E. Pinelli, J. Kallerhoff , M. Kaemmerer, A. Tarigo, M. Shahid, M. Guiresse, P. Pradere and C. Dumat . 2008. A field study of lead phytoextraction by various scented Pelargonium cultivars. Chemosphere. 71(11):2187-2192. https://doi.org/10.1016/j. chemosphere.2008.02.013

Chiban, M., A. Soudani, F. Sinan, S. Tahrouch, M. Persin. 2011. Characterization and Application of Dried Plants to Remove Heavy Metals, Nitrate, and Phosphate Ions from Industrial Wastewaters. CLEAN - Soil Air Water. 39(4):376-383. https://doi.org/10.1002/ clen. 201000127

Emamverdian, A., D. Yulong, M. Farzad and Xie. Yinfeng. 2015. Heavy metal stress and some mechanisms of plant defense response. Sci. World J. 1-18. https://doi. org/10.1155/2015/756120

Foy, C.D., R.L. Chaney and M. White. 2005.The physiology of metal toxicity in plants. Ann Rev Plant Physiol. J. 29:511-566. https://doi. org/10.1146/annurev.pp.29.060178.002455

Hasan, M.d., I. Kamrul, M. Sh. Ara, M. Alam and K.Yearul. 2021. Phytochemistry, pharmacological activity, and potential health benefits of Glycyrrhiza glabra. Heliyon J. 7: 6. https:// doi.org/10.1016/j.heliyon.2021.e07240

Hussain, A., N. Abbas, F. Arshad, M. Akram, Z. Igbal Khan, K. Ahmad, M. Mansha and F.
Mirzaei. 2013. Effects of diverse doses of Lead $(\mathrm{Pb})$ on different growth attributes of Zea Mays L. Agric. Sci. 4: 262-265. https://doi. org/10.4236/as.2013.45037

Jaishankar, M.T. Tseten, N. Anbalagan, B.B. Mathew and K.N. Beeregowda. 2014. Toxicity, mechanism and health effects of some heavy metals. Interdiscip. Toxicol. 7: 60-72. https:// doi.org/10.2478/intox-2014-0009

Jonas, L., L. Louis, G. Zvobgo, M. Eusi, A. Richmond, L. Fu, S. Naz, M. Mwamba, R. Prince, M. Mundende and G. Zhang. 2020. Physiological and molecular mechanisms of cobalt and copper interaction in causing phytotoxicity to two barley genotypes differing in Co tolerance. Ecotoxicol. Environ. Safety. 187: 109866. https://doi.org/10.1016/j.ecoenv.2019.109866

Kakkalameli, S., B.D. Zharuddin, M. Govindappa and T. C. Taranath. 2021. Effect of Chromium on morphological and biochemical responses on aquatic macrophyte Pistia stratiotes L. (Water lettuce). IJPSR. 12(1): 633-639.

Lowery, O.H., J.R. Nira and A.F. Lewis. 1951. Rose JR. Protein measurement with the Folin phenol reagent. Biochem. 265-275. https://doi. org/10.1016/S0021-9258(19)52451-6

Morrissey, J., I.R. Baxter, J. Lee, L. Li, B. Lahner, N. Grotz, J. Kaplan, D.E. Salt and M.L. Guerinot. 2009. The ferroportin metal efflux proteins function in iron and cobalt homeostasis in Arabidopsis. Plant Cell. 21: 3326- 3338. https://doi.org/10.1105/tpc.109.069401

Oladele, E.O., O.O. Adewumi, T. Yahaya and I.A. Taiwo. 2019. Response of Bambara groundnut (Vigna subterranean L.) and Maize (Zea mays L.) to heavy metal stress. Beni-Suef Univ. J. Basic Appl. Sci. 8:19. https://doi.org/10.1186/ s43088-019-0024-x

Pearson, D., H.K. Melon and S. Ronald. 1976. Chemical Analysis of Food,8th edition. Churchill Livingstone. Pp 5-63.

Pilon-Smits, E.A., C.F. Quinn, W. Tapken, M. Malagoli, and M. Schiavon. 2009. Physiological functions of beneficial elements. Curr. Opin. Plant Biol. 12: 267- 274. https://doi. org/10.1016/j.pbi.2009.04.009

Porwal O., Sh. Muath, T.A. Esra, U. Subasini, A. Javed and T. Amani. 2019. Silybum marianum (Milk Thistle): Review on Its chemistry, morphology, ethnomedical uses, phytochemistry and pharmacological activities. J. Drug Delivery 
Ther. 9(5):199-206. https://doi.org/10.22270/ jddt.v9i5.3666

Selvaraj, K. 2018. Effect of Nickel Chloride on the Growth and Biochemical Characteristics of Phaseolus Mongol. JOJ Sci. 1: 1.

Syed, K.M. and A.A. Meshari. 2018. Copper (Cu) an Essential Redox-Active Transition Metal in
Living System A Review Article. Am. J. Anal. Chem. 9:1.

Tamás, M.J., S.K. Sharma, S. Ibstedt, T. Jacobson and P. Christen. 2014. Heavy metals and metalloids as a cause for protein misfolding and aggregation. Biomolecules. 4: 252-267. https:// doi.org/10.3390/biom4010252 